\title{
BMJ Open Diabetes mellitus and the risk of fractures at specific sites: a meta-analysis
}

\author{
Hao Wang, Ying Ba, Qian Xing, Jian-Ling Du
}

To cite: Wang $\mathrm{H}, \mathrm{Ba} \mathrm{Y}$, Xing $\mathrm{Q}$, et al. Diabetes mellitus and the risk of fractures at specific sites: a meta-analysis. BMJ Open 2019;9:e024067. doi:10.1136/ bmjopen-2018-024067

- Prepublication history and additional material for this paper are available online. To view these files, please visit the journal online (http://dx.doi. org/10.1136/bmjopen-2018024067).

Received 8 May 2018 Revised 5 October 2018 Accepted 2 November 2018

Check for updates

(C) Author(s) (or their employer(s)) 2019. Re-use permitted under CC BY-NC. No commercial re-use. See rights and permissions. Published by BMJ.

Department of Endocrinology, First Affiliated Hospital of Dalian Medical University, Dalian, China

Correspondence to

Hao Wang;

wanghaodl@126.com

\section{ABSTRACT}

Objective Diabetes mellitus (DM) is associated with an increased fracture risk; however, the impact of DM and subsequent fracture at different sites and the associations according to patient characteristics remain unknown.

Design Meta-analysis

Data sources The PubMed, EMBASE and Cochrane

Library databases were searched from inception to March 2018.

Eligibility criteria We included prospective and retrospective cohort studies on the associations of DM and subsequent fracture risk at different sites.

Data extraction and synthesis Two authors independently extracted data and assessed the study quality. Relative risks (RRs) with $95 \%$ Cls were calculated using a random-effects model, and the heterogeneity across the included studies was evaluated using $\mathrm{I}^{2}$ and $Q$ statistics.

Results Overall, DM was associated with an increased risk of total (RR: $1.32 ; 95 \% \mathrm{Cl} 1.17$ to 1.48; $p<0.001$ ), hip (RR: $1.77 ; 95 \% \mathrm{Cl} 1.56$ to 2.02 ; $\mathrm{p}<0.001$ ), upper arm (RR: $1.47 ; 95 \% \mathrm{Cl} 1.02$ to 2.10 ; $\mathrm{p}=0.037$ ) and ankle fractures (RR: $1.24 ; 95 \% \mathrm{Cl} 1.10$ to $1.40 ; p<0.001)$, whereas DM had no significant impact on the incidence of distal forearm (RR: 1.02; $95 \% \mathrm{Cl} 0.88$ to $1.19 ; \mathrm{p}=0.809$ ) and vertebral fractures (RR: $1.56 ; 95 \% \mathrm{Cl} 0.78$ to $3.12 ; p=0.209$ ). RR ratios suggested that compared with patients with type $2 \mathrm{DM}$ (T2DM), patients with type 1 DM (T1DM) had greater risk of total (RR: $1.24 ; 95 \% \mathrm{Cl} 1.08$ to $1.41 ; \mathrm{p}=0.002$ ), hip (RR: $3.43 ; 95 \% \mathrm{Cl} 2.27$ to $5.17 ; p<0.001$ ) and ankle fractures (RR: $1.71 ; 95 \% \mathrm{Cl} 1.06$ to 2.78; $p=0.029$ ). Although no other significant differences were observed between subgroups, the association of DM with upper arm or ankle, vertebrae and total fracture differed according to sex, study design and country, respectively.

Conclusions Patients with DM had greater risks of total, hip, upper arm and ankle fractures, with T1DM having a more harmful effect than T2DM.

\section{INTRODUCTION}

Diabetes mellitus (DM) is considered a major global public health problem that is likely to be among the five leading causes of disease burden, with an estimated global prevalence of $4.4 \%$, by $2030 .{ }^{1}$ Age is an important factor, with the majority of patients with DM aged $>65$ years. ${ }^{2}$ Previous studies have confirmed the harmful impact
Strengths and limitations of this study

- The current study included articles that were based on cohort study designs, which could eliminate various confounding factors.

- A large sample size of patients was included; thus, our findings are potentially more robust than those of any individual study.

- Diabetes mellitus (DM) diagnosis in individual studies was not consistent, which might have introduced confounding to the representative DM cohort.

- The adjusted models differed across the included studies, and the factors in these models might have played an important role in the development of fractures.

of DM on the risk of vascular outcomes, ${ }^{34}$ cancer at different sites ${ }^{5}$ and renal dysfunction. ${ }^{6}$ Due to DM, patients might have altered calcium metabolism, ${ }^{7}$ increased bone turnover ${ }^{8}$ and reduced bone mineral density (BMD), ${ }^{9}$ which in turn may influence the risk of fractures in patients with DM. However, previous meta-analyses reported different strengths of association between DM and the risk of fractures in type 1 and type 2DM (T1DM and T2DM, respectively), ${ }^{10} 11$ which highlights the need to verify and evaluate the association between DM and fracture at other sites.

Previous studies have illustrated the association between clinical factors and the risk of fractures at different sites. ${ }^{12} 13$ However, due to limited sample sizes, the associations in patients with specific characteristics were not determined, and thus, there is a need for further verification. Furthermore, clinicians and patients could benefit from the assessment of fracture risk in patients. Therefore, it is of critical importance that clinicians are able to identify patients with DM and the risk of fracture at different sites in patients with specific characteristics, to implement preventive strategies in each of such subsets. Vestergaard conducted a meta-analysis based on 16 observational studies and found that both T1DM and 


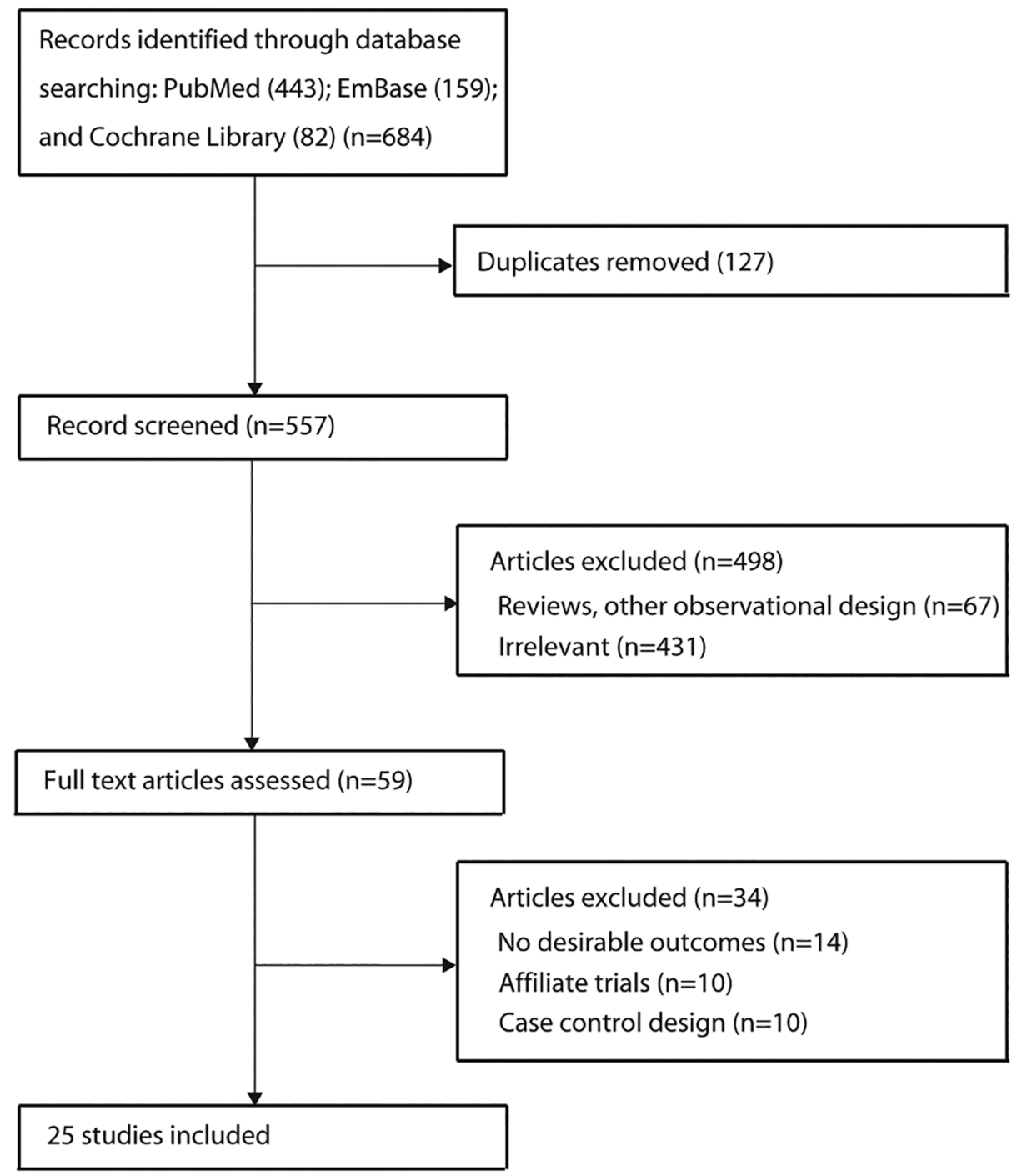

Figure 1 Study selection process.

T2DM are associated with an increased risk of hip fracture and that BMD is increased in T2DM but decreased in T1DM. However, fractures at other sites and differences according to country, sex and study design were not separately assessed. ${ }^{10}$ Fan et al indicated that patients with DM have a greater risk of hip fractures compared with those without DM and that this association was more pronounced in patients with T1DM. ${ }^{11}$ However, the stratified results of individual studies should first be pooled using fixed-effect models, and the summary results of the included studies should be calculated using random-effects models. Furthermore, the associations between DM and the risk of fracture at other sites, including total, distal forearm, upper arm, ankle and vertebra, were not assessed. Therefore, this study was conducted to determine whether the association between DM and fracture at different sites differed according to patient characteristics.

\section{MATERIAL AND METHODS \\ Search strategy and inclusion criteria}

This meta-analysis was performed according to the Preferred Reporting Items for Systematic Reviews and Meta-Analysis statement (Checklist S1).${ }^{14}$ The PubMed, EMBASE and Cochrane Library databases were searched for studies from their inception to March 2018 using the following core search terms: ('diabetes' OR 'diabetes mellitus' OR 'glycuresis') AND ('fractures, spontaneous' OR 'hip fractures' OR 'osteoporotic fractures' OR 'fractures, compression' OR 'spinal fractures' OR 'fracture') AND ('epidemiologic study' OR 'cohort'). The details of the search strategy for PubMed are shown in the online supplementary file 1 . We restricted the search to include only studies published in English. Furthermore, manual searches of reference lists of relevant studies were performed to identify additional eligible studies. The study topic, design, exposure and fractures at different sites were used to identify relevant studies. 
Table 1 Baseline characteristic of studies included

\begin{tabular}{|c|c|c|c|c|c|c|c|c|}
\hline Study & $\begin{array}{l}\text { Publication } \\
\text { year }\end{array}$ & Country & $\begin{array}{l}\text { Study } \\
\text { design }\end{array}$ & $\begin{array}{l}\text { Sample } \\
\text { size }\end{array}$ & $\begin{array}{l}\text { Mean age } \\
\text { (years) }\end{array}$ & $\begin{array}{l}\text { Percentage } \\
\text { men (\%) }\end{array}$ & $\begin{array}{l}\text { Number of } \\
\text { DM }\end{array}$ & $\begin{array}{l}\text { Follow-up } \\
\text { (years) }\end{array}$ \\
\hline $\mathrm{CHS}^{25}$ & 2011 & USA & Pro & 5641 & 72.8 & 42.0 & 1456 & 10.9 \\
\hline FRAILCO ${ }^{27}$ & 2016 & Sweden & Pro & 428305 & 80.8 & 42.4 & 84702 & 1.3 \\
\hline Dobnig $^{28}$ & 2006 & Australia & Pro & 1664 & $>70.0$ & 0.0 & 583 & 2.0 \\
\hline SCI-DC ${ }^{31}$ & 2014 & UK & Retro & 3801874 & 20.0-84.0 & NA & 201874 & NA \\
\hline SIDIAP 32 & 2015 & Spain & Pro & 171931 & 62.6 & 56.5 & 58483 & 2.6 \\
\hline THIN $^{33}$ & 2015 & UK & Retro & 334266 & 34.0 & 56.1 & 30394 & 5.7 \\
\hline $\mathrm{NHS}^{34}$ & 2006 & USA & Pro & 109983 & 56.3 & 0.0 & 8640 & 20.0 \\
\hline $\begin{array}{l}\text { The Blue Mountains Eye } \\
\text { Study }^{38}\end{array}$ & 2001 & Australia & Pro & 3654 & 66.2 & 43.3 & 216 & 5.0 \\
\hline $\begin{array}{l}\text { Singapore Chinese Health } \\
\text { Study }^{39}\end{array}$ & 2010 & Singapore & Pro & 63257 & 56.4 & 44.3 & 5668 & 12.0 \\
\hline Meyer $^{40}$ & 1993 & Norway & Pro & 52313 & $35.0-49.0$ & 51.6 & 288 & 10.9 \\
\hline Lipscombe $^{41}$ & 2007 & Canada & Retro & 598812 & $>66.0$ & 50.6 & 197412 & 6.1 \\
\hline Melton $^{42}$ & 2008 & USA & Retro & 1964 & 61.7 & 51.0 & 1964 & 11.8 \\
\hline $\begin{array}{l}\text { Nord-Trùndelag Health } \\
\text { Survey }^{43}\end{array}$ & 1999 & Norway & Pro & 35444 & $50.0-74.0$ & 47.5 & 1850 & 9.0 \\
\hline Majumdar $^{47}$ & 2016 & Canada & Retro & 57938 & 64.3 & 0.0 & 8840 & 7.2 \\
\hline $\mathrm{SOF}^{48}$ & 2001 & USA & Pro & 9754 & 71.0 & 0.0 & 657 & 9.4 \\
\hline Chen $^{49}$ & 2008 & China & Retro & 969820 & 60.0 & 47.0 & 484787 & 6.0 \\
\hline
\end{tabular}

NA, not applicable; Pro, prospective; Retro, retrospective.

The literature search and study selection processes were independently conducted by two authors using a standardised approach. Any inconsistency was resolved by group discussion until a consensus was reached. The study inclusion criteria are as follows: (1) a prospective or retrospective cohort design; (2) participants with T1DM or T2DM; and (3) report of the effect estimates of comparisons between DM and non-DM and the risk of fracture at different sites. We excluded case-control studies due to various confounding factors that could bias the results.

\section{Data collection and quality assessment}

Data extraction and quality assessment were conducted independently by two authors. The information was examined and adjudicated independently by an additional author by referring to the original studies. The abstracted data included the first author or study group's name, publication year, country, study design, sample size, mean patient age, percentage of men, number of patients with DM, percentage of current smokers, mean body mass index (BMI), follow-up duration, DM diagnosis and adjusted factors. The outcome variable was abstracted using the effect estimate with corresponding 95\% CIs. If the study reported several multivariable adjusted effect estimates, the effect estimate was maximally adjusted to account for potential confounders. The Newcastle-Ottawa Scale (NOS), which has been validated by evaluating the quality of observational studies in meta-analyses, was 


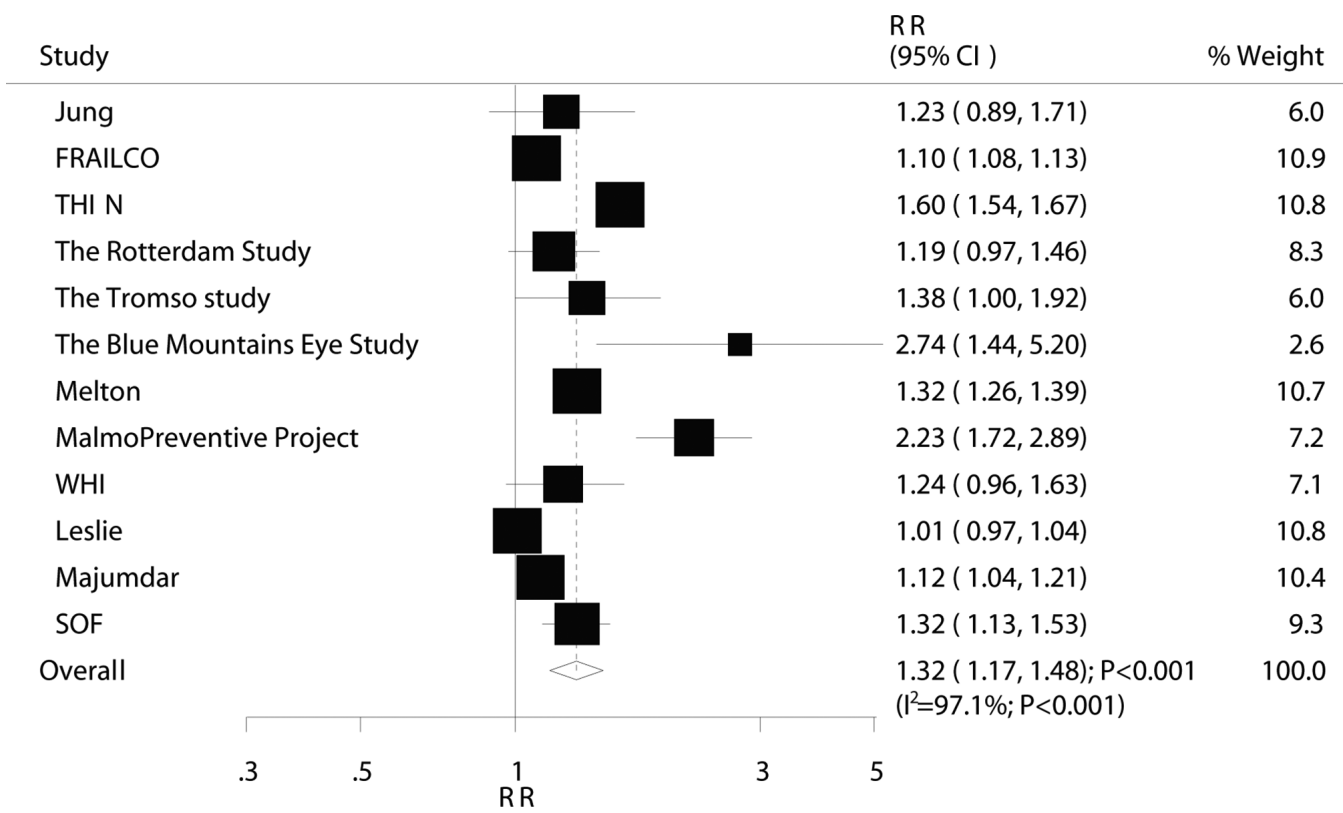

Figure 2 Association between DM and the risk of total fractures. DM, diabetes mellitus.

used to evaluate the methodological quality. ${ }^{15}$ The NOS was based on selection (four items with a total of four stars), comparability (one item with a total of two stars) and outcome (three items with a total of three stars) with a total of nine stars for assessment.

\section{Statistical analysis}

The association between DM and the subsequent risk of fractures at different sites was based on effect estimates and corresponding 95\% CIs in each study. We first used the fixed-effect model to calculate the summary relative risk (RR) and 95\% CI for the association between DM and fractures in individual studies. ${ }^{16}$ We then combined the RRs of fracture risk in individual with DM versus without DM using a random-effects model. ${ }^{17}$ Heterogeneity among the included studies was assessed using $\mathrm{I}^{2}$ and $\mathrm{Q}$ statistics; and $p$ values $<0.10$ were considered to indicate significant heterogeneity. ${ }^{18} 19$ Sensitivity analyses were conducted by removing each individual study from the overall analysis. ${ }^{20}$ Stratified analyses were conducted for total, hip, distal forearm, upper arm, ankle and vertebral fractures based on country, DM type, sex and study design. The RR ratio and its 95\% CI were estimated using specific RR and 95\% CI according to country, DM types, sex and study design. ${ }^{21}{ }^{22}$ Funnel plot, Egger ${ }^{23}$ and Begg ${ }^{24}$ tests were used to evaluate publication bias for total fractures. $P$ values were two-sided, and those $<0.05$ were considered statistically significant across the included studies. The statistical analyses were conducted using STATA (V.12.0).

\section{Patient and public involvement}

No patients were involved in the development of the research question, outcome measures, design, study implementation, dissemination of the results of the research to the study participants or interpretation of the results.

\section{RESULTS}

\section{Search of published literature}

A total of 684 articles were identified from our electronic search, of which 602 were excluded due to duplication,

\begin{tabular}{|c|c|c|c|c|c|c|c|}
\hline Factors & Subsets & $\mathrm{RR}$ and $95 \% \mathrm{Cl}$ & $P$ value & $I^{2}(\%)$ & $\begin{array}{l}P \text { value for } \\
\text { heterogeneity }\end{array}$ & $\begin{array}{l}\text { Ratio of RR between } \\
\text { subgroups }\end{array}$ & $\begin{array}{l}P \text { value for } \\
\text { ratios of } R R\end{array}$ \\
\hline \multirow[t]{2}{*}{ Country } & Western & 1.32 (1.17 to 1.50$)$ & $<0.001$ & 97.4 & $<0.001$ & $1.07(0.76-1.52)$ & 0.690 \\
\hline & Eastern & 1.23 (0.89 to 1.70$)$ & 0.214 & - & - & & \\
\hline \multirow[t]{2}{*}{ DM types } & I & 1.51 (1.35 to 1.68$)$ & $<0.001$ & 78.3 & $<0.001$ & $1.24(1.08-1.41)$ & 0.002 \\
\hline & ॥ & $1.22(1.13$ to 1.31$)$ & $<0.001$ & 83.0 & $<0.001$ & & \\
\hline \multirow[t]{2}{*}{ Sex } & Men & 1.49 (1.20 to 1.85$)$ & $<0.001$ & 96.1 & $<0.001$ & $1.14(0.89-1.46)$ & 0.313 \\
\hline & Women & 1.31 (1.16 to 1.49$)$ & $<0.001$ & 92.8 & $<0.001$ & & \\
\hline \multirow[t]{2}{*}{ Study design } & Prospective & 1.32 (1.20 to 1.46$)$ & $<0.001$ & 83.4 & $<0.001$ & $1.01(0.84-1.21)$ & 0.936 \\
\hline & Retrospective & 1.31 (1.12 to 1.54$)$ & 0.001 & 97.6 & $<0.001$ & & \\
\hline
\end{tabular}

$\mathrm{DM}$, diabetes mellitus; $\mathrm{RR}$, relative risk. 


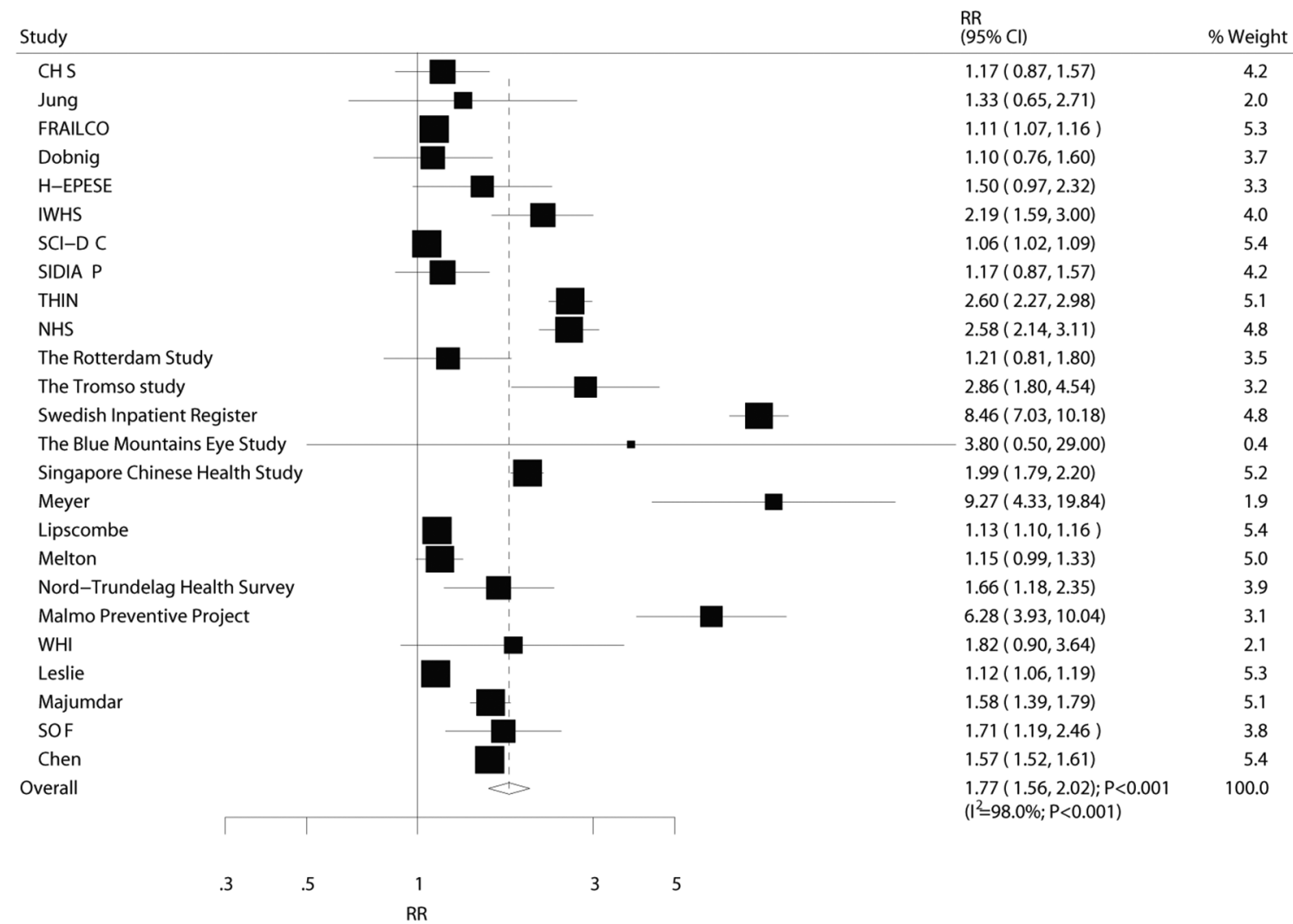

Figure 3 Association between DM and the risk of hip fracture. DM, diabetes mellitus.

irrelevance and other design issues. We retrieved the full text for the remaining 59 studies and selected 25 cohort studies for the final analysis after detailed evaluations. ${ }^{25-49}$ The manual search of the reference lists of relevant reviews did not yield any new eligible studies. The results of the study selection process are shown in figure 1, and the general characteristics of the included studies are presented in table 1 and the online supplementary table S1.

\section{Study characteristics}

Of the 25 included studies, 16 used a prospective cohort design $^{25}$ 27-30 32 34-36 38-40 43-45 48 while the remaining 9 studies used a retrospective cohort design. 2631333741424647
The sample sizes ranged from 1664 to 3801874 , while the number of patients with DM ranged from 166 to 484787 . Twelve studies were conducted in the USA, Australia or

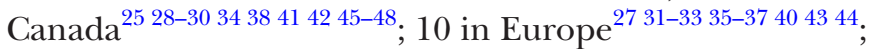
and the remaining 3 in Asia. ${ }^{26} 3949$ The results of total fractures were available in 12 studies, hip fractures in all studies, distal forearm fractures in 8 studies, upper arm fractures in 6 studies, ankle fractures in 4 studies, and vertebral fractures in 6 studies. Study quality was evaluated by NOS, and a study with seven or more stars was regarded as a high-quality study. Overall, seven, eight, six and the remaining four studies had scores of 9, 8, 7 and 6 , respectively (online supplementary table $\mathrm{S} 2$ ).

\begin{tabular}{|c|c|c|c|c|c|c|c|}
\hline Factors & Subsets & $\mathrm{RR}$ and $95 \% \mathrm{Cl}$ & $P$ value & $I^{2}(\%)$ & $\begin{array}{l}\text { P value for } \\
\text { heterogeneity }\end{array}$ & $\begin{array}{l}\text { Ratio of RR between } \\
\text { subgroups }\end{array}$ & $\begin{array}{l}P \text { value for } \\
\text { ratios of } R R\end{array}$ \\
\hline & Eastern & 1.72 (1.39 to 2.14$)$ & $<0.001$ & 89.5 & $<0.001$ & & \\
\hline DM types & I & 4.35 (2.91 to 6.49$)$ & $<0.001$ & 95.4 & $<0.001$ & $3.43(2.27-5.17)$ & $<0.001$ \\
\hline Sex & Women & 2.04 (1.76 to 2.37$)$ & $<0.001$ & 97.5 & $<0.001$ & & \\
\hline \multirow[t]{2}{*}{ Study design } & Prospective & 2.02 (1.71 to 2.39$)$ & $<0.001$ & 91.4 & $<0.001$ & 1.09 (0.87-1.36) & 0.472 \\
\hline & Retrospective & 1.86 (1.60 to 2.16$)$ & $<0.001$ & 98.7 & $<0.001$ & & \\
\hline
\end{tabular}

$\mathrm{DM}$, diabetes mellitus; $\mathrm{RR}$, relative risk. 


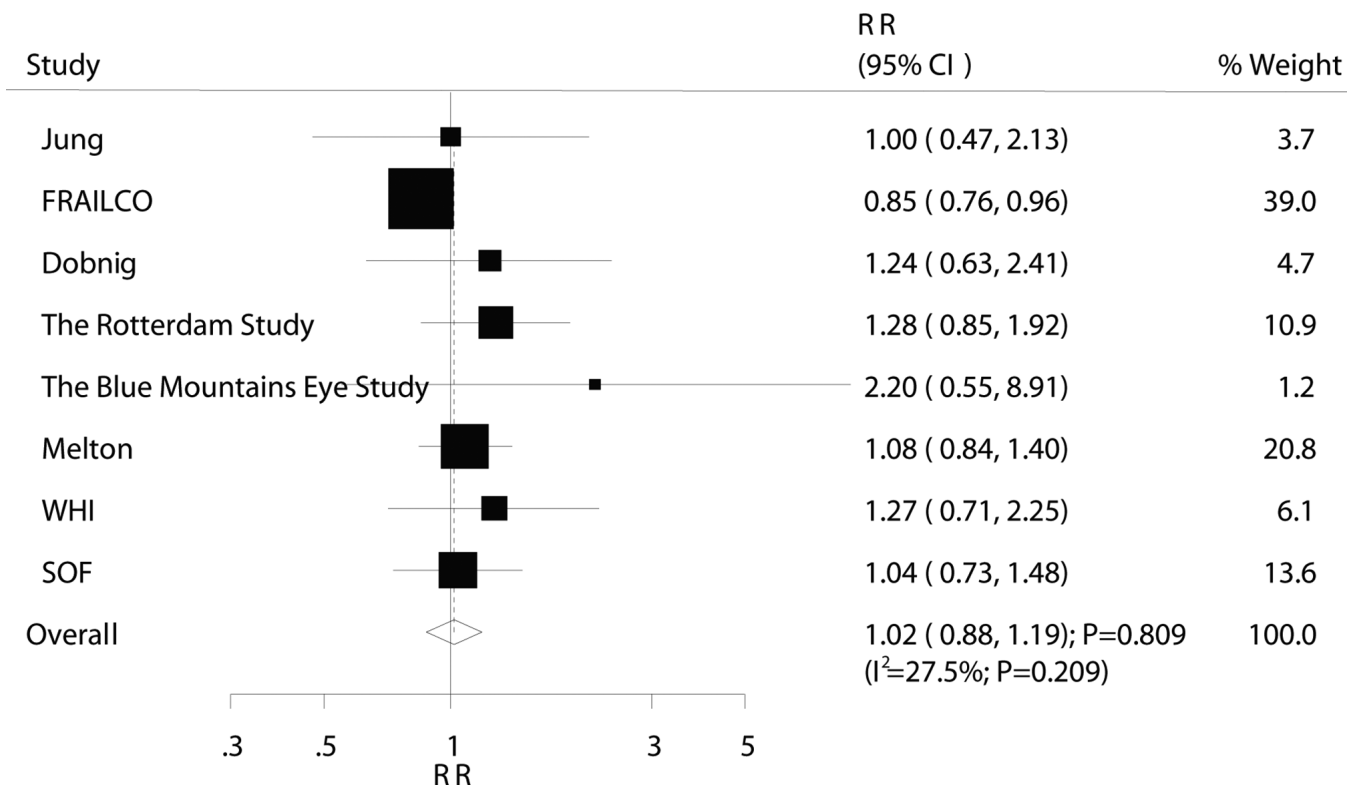

Figure 4 Association between DM and the risk of distal forearm fracture. DM, diabetes mellitus; RR, relative risk.

\section{Total fractures}

Overall, 12 studies reported an association between DM and the risk of total fractures. The summary RR indicated that compared with non-DM, having DM was associated with an increased risk of total fractures (RR: 1.32; 95\% CI 1.17 to 1.48 ; $\mathrm{p}<0.001$; figure 2 ) and substantial heterogeneity was detected $\left(\mathrm{I}^{2}=97.1 \% ; \mathrm{p}<0.001\right)$. The sensitivity analysis revealed that the conclusion was not affected by the sequential exclusion of individual studies from the overall analysis (online supplementary table S3). A subgroup analysis of total fractures based on country, DM type, sex and study design was performed. The results showed that patients with DM had an increased risk of total fractures in nearly all subsets except for studies conducted in Eastern countries (table 2). Furthermore, the RR ratio for the comparison between T1DM and T2DM of the risk of total fractures was significantly increased, and the association was also statistically significant (ratio of RR: 1.24; $95 \%$ CI 1.08 to 1.41 ; $\mathrm{p}=0.002$; table 2 ).

\section{Hip fracture}

In total, 25 studies reported an association between DM and the risk of hip fracture. In the pooled analysis, the comparison of DM and non-DM showed a harmful effect on hip fracture (RR: 1.77; 95\% CI 1.56 to 2.02; $\mathrm{p}<0.001$; figure 3). Although substantial heterogeneity was detected across the included studies $\left(\mathrm{I}^{2}=98.0 \%\right.$; $\left.\mathrm{p}<0.001\right)$, the conclusion did not change after sequential exclusion of individual studies (online supplementary table S4). The results of subgroup analysis for hip fracture are listed in table 3, and all results indicated that DM had a harmful effect on hip fracture. Furthermore, the RR ratio showed a statistically significant association between DM and the risk of hip fracture in T1DM when compared with that of T2DM (ratio of RR: 3.43; 95\% CI 2.27 to 5.17; p<0.001).

\section{Distal forearm fracture}

Overall, eight studies reported an association between DM and the risk of distal forearm fracture. The summary RR

\begin{tabular}{|c|c|c|c|c|c|c|c|}
\hline Factors & Subsets & $\mathrm{RR}$ and $95 \% \mathrm{Cl}$ & $P$ value & $I^{2}(\%)$ & $\begin{array}{l}\mathbf{P} \text { value for } \\
\text { heterogeneity }\end{array}$ & $\begin{array}{l}\text { Ratio of RR } \\
\text { between subgroups }\end{array}$ & $\begin{array}{l}P \text { value for } \\
\text { ratios of } R R\end{array}$ \\
\hline & Eastern & 1.00 (0.47 to 2.13$)$ & 1.000 & - & - & & \\
\hline DM types & 1 & 1.09 (0.43 to 2.75$)$ & 0.861 & 78.3 & 0.032 & $1.12(0.43-2.94)$ & 0.812 \\
\hline \multirow[t]{2}{*}{ Sex } & Men & $1.04(0.66$ to 1.65$)$ & 0.863 & 58.5 & 0.090 & $1.12(0.70-1.80)$ & 0.644 \\
\hline & Women & $0.93(0.82$ to 1.05$)$ & 0.257 & 6.3 & 0.380 & & \\
\hline \multirow[t]{2}{*}{ Study design } & Prospective & 1.00 (0.83 to 1.19$)$ & 0.982 & 41.0 & 0.094 & $0.93(0.69-01.27)$ & 0.662 \\
\hline & Retrospective & 1.07 (0.84 to 1.37$)$ & 0.565 & 0.0 & 0.944 & & \\
\hline
\end{tabular}

$\mathrm{DM}$, diabetes mellitus; $\mathrm{RR}$, relative risk. 


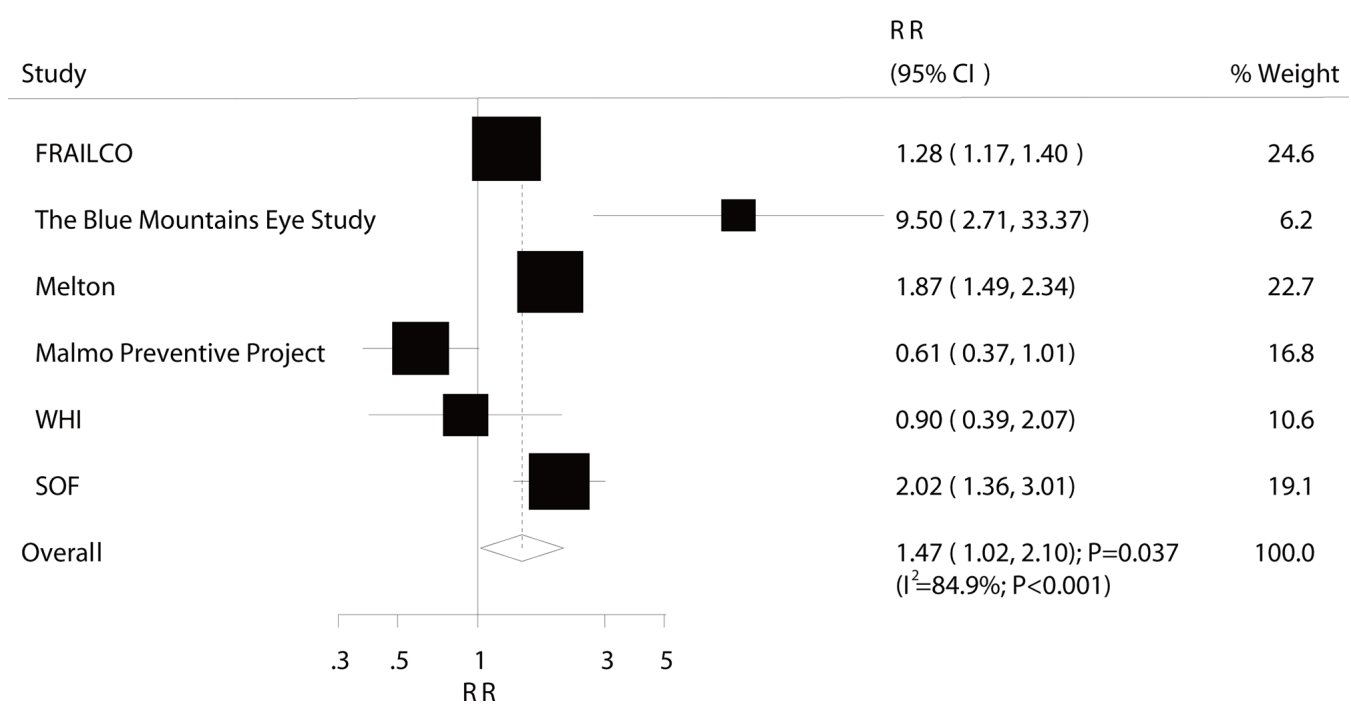

Figure 5 Association between DM and the risk of upper arm fracture. DM, diabetes mellitus.

showed that DM was not associated with the risk of distal forearm fracture (RR: 1.02; 95\% CI 0.88 to $1.19 ; \mathrm{p}=0.809$; figure 4) and non-significant heterogeneity was observed $\left(\mathrm{I}^{2}=27.5 \% ; \mathrm{p}=0.209\right)$. The sensitivity analysis suggested that the conclusion was not affected by the exclusion of any specific study (online supplementary table S5). The subgroup analysis indicated that the conclusions in each subset continued to be non-significant and no significant differences were observed between subgroups based on country, DM type, sex or study design (table 4).

\section{Upper arm fracture}

In total, six studies reported an association between DM and the risk of upper arm fracture. Compared with non-DM, DM had a higher risk of upper arm fracture (RR: 1.47; 95\% CI: 1.02 to 2.10; $\mathrm{P}=0.037$; figure 5) and evidence of significant heterogeneity was observed $\left(I^{2}=84.9 \%\right.$; $\mathrm{P}<0.001)$. The sensitivity analysis indicated that the results varied possibly due to the smaller number of studies on fractures occurring in the upper arm (online supplementary table S6). The subgroup analysis indicated that DM had no significant impact on upper arm fracture in men, whereas this risk increased in other subsets (table 5).

\section{Ankle fracture}

In all, four studies reported an association between DM and the risk of ankle fracture. The risk of ankle fracture significantly increased in patients with DM (RR: 1.24; $95 \%$ CI 1.10 to $1.40 ; \mathrm{p}<0.001$; figure 6 ) with no evidence of heterogeneity $\left(I^{2}=0.0 \% ; p=0.400\right)$. The results of the sensitivity analysis were consistent with those of the overall analysis and are shown in the online supplementary table S7. The subgroup analysis showed no association between DM and ankle fracture risk in men, whereas in other subsets, the risk was significantly increased (table 6). Furthermore, patients with T1DM were at a greater risk of ankle fracture than were patients with T2DM (ratio of RR: $1.71 ; 95 \%$ CI 1.06 to $1.78 ; \mathrm{p}=0.029$; table 6 ).

\section{Vertebrae fracture}

Overall, six studies reported an association between DM and the risk of vertebrae fracture. The results of pooled analysis indicated no significant association between DM and vertebrae fracture risk (RR: $1.56 ; 95 \% \mathrm{CI} 0.78$ to 3.12; $\mathrm{p}=0.209$; figure 7); and there was evidence of significant heterogeneity $\left(\mathrm{I}^{2}=96.3 \% ; \mathrm{p}<0.001\right)$. As a result, a

\begin{tabular}{|c|c|c|c|c|c|c|c|}
\hline Factors & Subsets & $\mathrm{RR}$ and $95 \% \mathrm{Cl}$ & $P$ value & $\mathrm{I}^{2}(\%)$ & $\begin{array}{l}\mathbf{P} \text { value for } \\
\text { heterogeneity }\end{array}$ & $\begin{array}{l}\text { Ratio of RR between } \\
\text { subgroups }\end{array}$ & $\begin{array}{l}P \text { value for } \\
\text { ratios of } R R\end{array}$ \\
\hline & Eastern & - & - & - & - & & \\
\hline DM types & 1 & 1.83 (1.41 to 2.39$)$ & $<0.001$ & 0.0 & 0.487 & $1.19(0.82-1.72)$ & 0.359 \\
\hline \multirow[t]{2}{*}{ Sex } & Men & 1.21 (0.80 to 1.83$)$ & 0.368 & 73.2 & 0.011 & $0.82(0.50-1.36)$ & 0.450 \\
\hline & Women & 1.47 (1.10 to 1.96$)$ & 0.009 & 79.1 & $<0.001$ & & \\
\hline \multirow[t]{2}{*}{ Study design } & Prospective & 1.38 (1.07 to 1.76$)$ & 0.011 & 76.0 & $<0.001$ & $0.80(0.47-1.36)$ & 0.412 \\
\hline & Retrospective & 1.72 (1.08 to 2.73$)$ & 0.022 & 68.5 & 0.075 & & \\
\hline
\end{tabular}

$\mathrm{DM}$, diabetes mellitus; $\mathrm{RR}$, relative risk. 


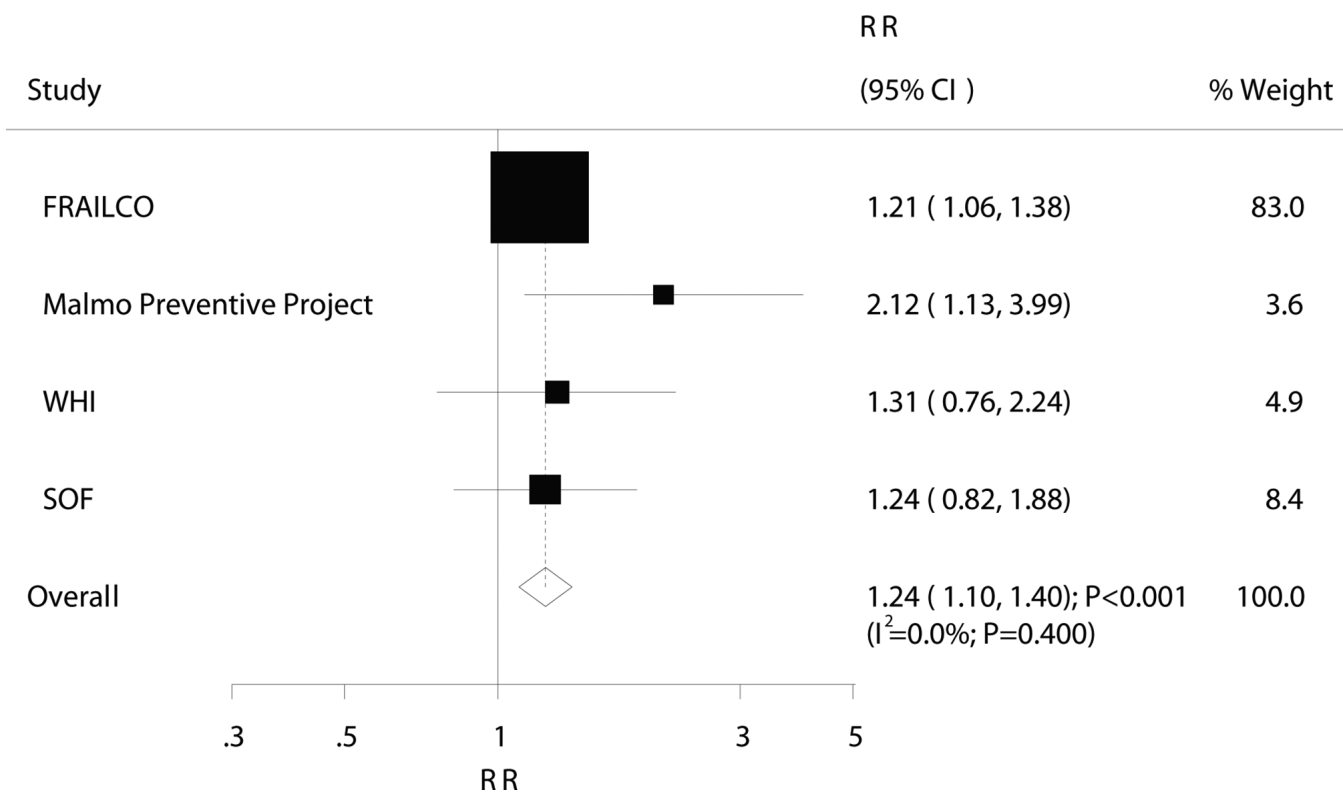

Figure 6 Association between DM and the risk of ankle fracture. DM, diabetes mellitus.

sensitivity analysis was conducted and although each study was sequentially excluded from the pooled analysis, the conclusion was not affected by the exclusion of any specific study (online supplementary table S8). The subgroup analysis indicated that DM was associated with an increased risk of vertebrae fracture in retrospective cohort studies, whereas no significant effect in other subsets and no difference between subgroups were observed (table 7).

\section{Publication bias}

From the review of the funnel plots, publication bias for total fractures could not be ruled out (figure 8). However, the Egger and Begg test results showed no evidence of publication bias ( $p$ value for Egger: 0.311; $p$ value for Begg: 0.537).

\section{DISCUSSION}

Due to the consideration that the characteristics of patients with DM might have affected the incidence of fractures at different sites, we used cohort studies to evaluate the correlations between DM and fractures according to country, DM type, sex, and study design. The meta-analysis included 7185572 participants from 16 prospective and 9 retrospective cohort studies with a broad range of individual characteristics. The findings of this study indicated that DM was associated with an elevated risk of total, hip, upper arm and ankle fractures but had no effect on distal forearm and vertebral fractures. The findings of the subgroup analyses were mostly consistent with those of the overall analysis except for those of total fracture in Eastern countries and upper arm and ankle fractures in men. Finally, compared with T2DM, T1DM was associated with a greater risk of total, hip and ankle fracture.

A previous study based on 14 observational studies evaluated the association between T1DM and the risk of fractures. ${ }^{50}$ The results indicated that T1DM was associated with a higher risk of total (RR, 3.16; $\mathrm{p}=0.002)$, hip (RR, 3.78; $\mathrm{p}<0.001)$ and spinal fractures (RR, 2.88; $\mathrm{p}<0.001)$. However, different study designs might bias this

\begin{tabular}{|c|c|c|c|c|c|c|c|}
\hline Factors & Subsets & $\mathrm{RR}$ and $95 \% \mathrm{Cl}$ & $P$ value & $I^{2}(\%)$ & $\begin{array}{l}\text { P value for } \\
\text { heterogeneity }\end{array}$ & $\begin{array}{l}\text { Ratio of RR between } \\
\text { subgroups }\end{array}$ & $\begin{array}{l}\text { P value for } \\
\text { ratios of } R R\end{array}$ \\
\hline \multirow[t]{2}{*}{ Country } & Western & 1.24 (1.10 to 1.40$)$ & $<0.001$ & 0.0 & 0.400 & - & - \\
\hline & Eastern & - & - & - & - & & \\
\hline \multirow[t]{2}{*}{ DM types } & 1 & 1.97 (1.24 to 3.14 ) & 0.004 & 29.3 & 0.234 & $1.71(1.06-2.78)$ & 0.029 \\
\hline & $\|$ & 1.15 (1.01 to 1.31$)$ & 0.029 & 0.0 & 0.886 & & \\
\hline \multirow[t]{2}{*}{ Sex } & Men & 1.35 (0.68 to 2.65 ) & 0.390 & 74.1 & 0.021 & $0.96(0.46-2.01)$ & 0.922 \\
\hline & Women & 1.40 (1.07 to 1.84$)$ & 0.014 & 51.6 & 0.083 & & \\
\hline \multirow[t]{2}{*}{ Study design } & Prospective & 1.24 (1.10 to 1.40$)$ & $<0.001$ & 0.0 & 0.400 & - & - \\
\hline & Retrospective & - & - & - & - & & \\
\hline
\end{tabular}

$\mathrm{DM}$, diabetes mellitus; $\mathrm{RR}$, relative risk. 


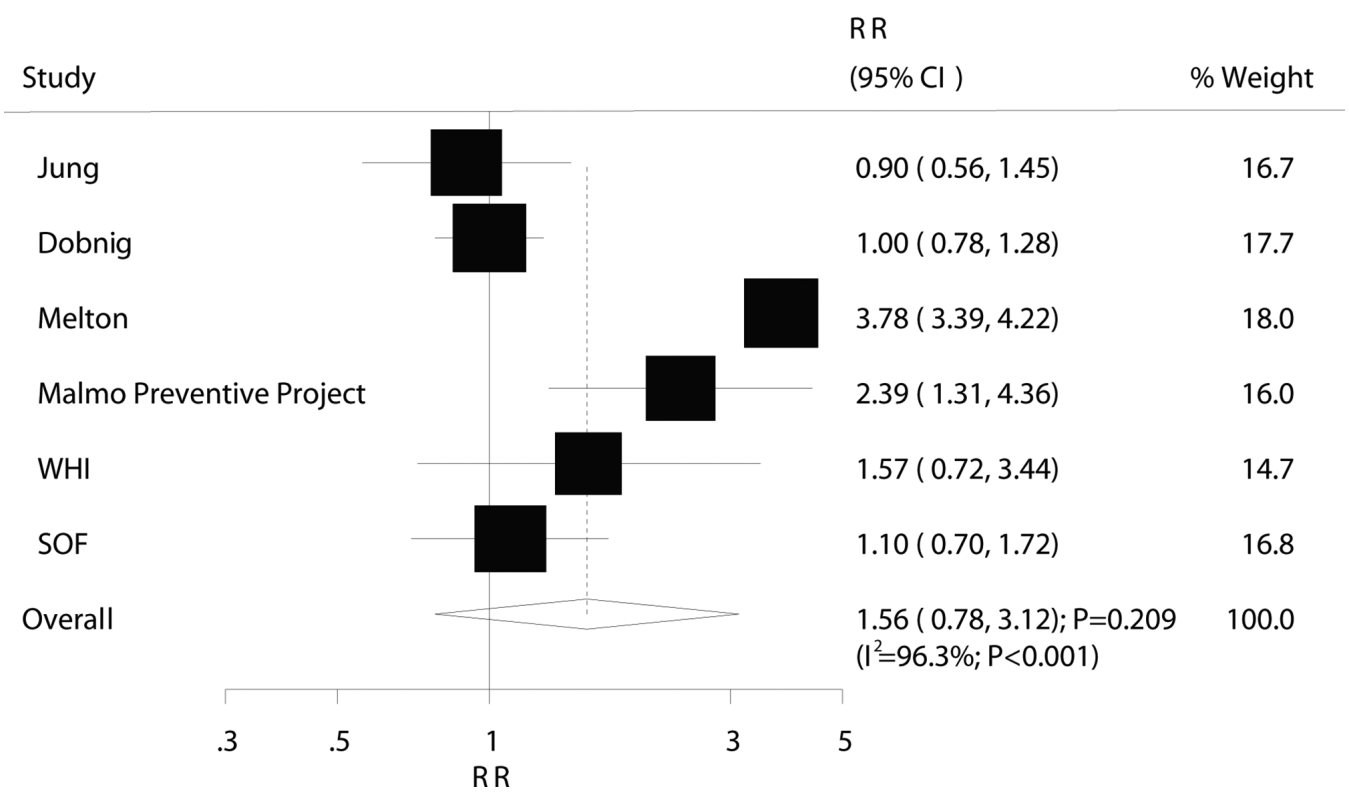

Figure 7 Association between DM and the risk of vertebrae fracture. DM, diabetes mellitus.

association and the role of the T2DM type was not evaluated in previous studies. Similar limitations of two other meta-analyses have already been described. ${ }^{10} 11$ Therefore, the present meta-analysis of available cohort studies was performed to address these limitations.

The pooled results showed a significantly increased risk of total, hip, upper arm and ankle fractures in patients with DM compared with those without DM; this result is consistent with those of previous studies. ${ }^{101150}$ However, several studies reported inconsistent results. After adjusting for BMI, sex, race and age, Strotmeyer et $a l^{25}$ indicated that T2DM had no significant effect on the risk of hip fracture. Jung $e t a l^{26}$ showed by the RR that in the T2DM cohort, increased risk of total and hip fractures occurred, although these increases were not statistically significant. One possible explanation for this could be the number of patients newly diagnosed with DM that might be higher than that reported in other studies; and the increase in insulin level might affect bone metabolism. Furthermore, a smaller sample size and a lower incidence of fracture events were associated with lower statistical power and broad 95\% CI in the previous study. Finally, the summary results for upper arm and ankle fractures might have varied due to the limited number of studies included; the interaction of these associations with age, severity of DM and antidiabetic drugs should be explored.

There were no significant differences between patients with DM and those without it with respect to distal forearm fracture. Most individual studies reported similar results, whereas the FRAILCO study indicated that DM was associated with a lower risk of distal forearm fracture. ${ }^{27}$ The reason for this difference could be the study compared patients taking oral antidiabetics with non-DM individuals. Furthermore, the incidence of distal forearm fracture might be underestimated in register-based data. Finally, distal forearm fractures usually develop earlier in life, and the age of the participants in the individual studies might play a confounding role. Similar results were found for vertebral fractures. Two of the included studies indicated that T2DM was associated with a higher risk of vertebral fractures. ${ }^{42} 44$ The reason for this finding could be the baseline levels of serum $\gamma$-glutamyl

\begin{tabular}{|c|c|c|c|c|c|c|c|}
\hline Factors & Subsets & $\mathrm{RR}$ and $95 \% \mathrm{Cl}$ & $P$ value & $I^{2}(\%)$ & $\begin{array}{l}\text { P value for } \\
\text { heterogeneity }\end{array}$ & $\begin{array}{l}\text { Ratio of RR between } \\
\text { subgroups }\end{array}$ & $\begin{array}{l}P \text { value for } \\
\text { ratios of } R R\end{array}$ \\
\hline \multirow[t]{2}{*}{ Country } & Western & 1.74 (0.82 to 3.69$)$ & 0.148 & 96.5 & $<0.001$ & $1.93(0.79-4.71)$ & 0.146 \\
\hline & Eastern & 0.90 (0.56 to 1.45$)$ & 0.664 & - & - & & \\
\hline \multirow[t]{2}{*}{ DM types } & 1 & - & - & - & - & - & - \\
\hline & ॥ & 1.74 (0.96 to 3.16$)$ & 0.070 & 96.7 & $<0.001$ & & \\
\hline \multirow[t]{2}{*}{ Sex } & Men & 2.26 (0.40 to 12.73$)$ & 0.354 & 88.9 & 0.003 & $1.42(0.23-8.85)$ & 0.706 \\
\hline & Women & 1.59 (0.88 to 2.87 ) & 0.125 & 84.1 & $<0.001$ & & \\
\hline \multirow[t]{2}{*}{ Study design } & Prospective & 1.36 (0.88 to 2.11$)$ & 0.167 & 66.4 & 0.018 & $0.54(0.25-1.14)$ & 0.105 \\
\hline & Retrospective & 2.54 (1.37 to 4.70$)$ & 0.003 & 96.1 & $<0.001$ & & \\
\hline
\end{tabular}

$\mathrm{DM}$, diabetes mellitus; $\mathrm{RR}$, relative risk. 


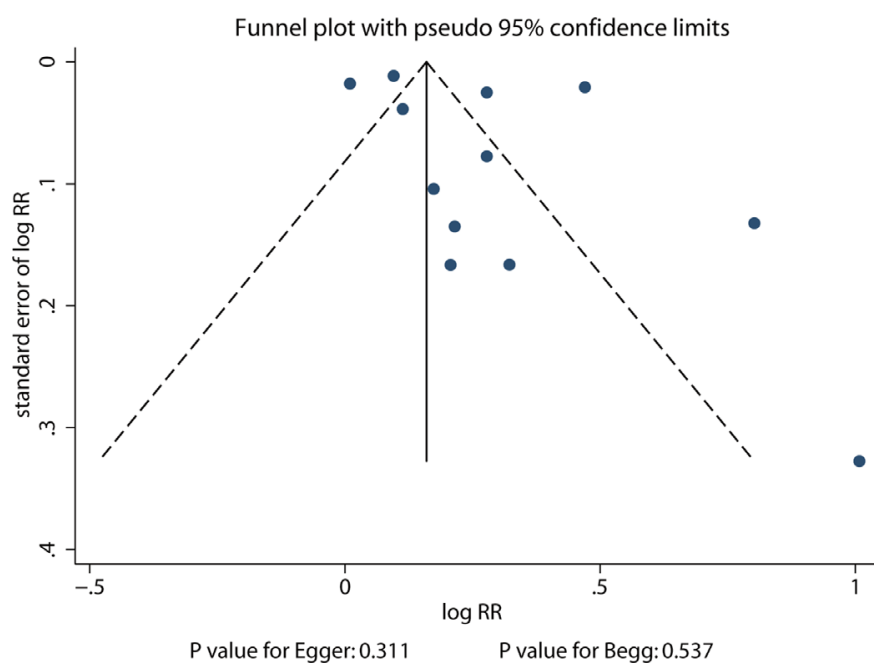

Figure 8 Publish bias for total fractures.

transferase and metabolic syndrome in women as well as alcohol overconsumption, which are associated with higher serum $\gamma$-glutamyl transferase levels in men, and may play an important role in the risk of vertebral and ankle fractures. ${ }^{51-53}$

The results of the stratified analysis were generally consistent with those of the overall analysis. However, two breakthroughs should be highlighted: (1) T1DM was associated with a higher risk of total, hip and ankle fractures compared with that in T2DM. The possible reasons for this include the different reasons for the incidence of fracture, such as differences in BMI between T1DM and T2DM, which might have played a protective role in fractures ${ }^{54}$ Furthermore, while BMI is a major determinant of BMD and fracture risk, not all studies adjusted for the impact of BMI, which could have affected the intrinsic correlation of DM and fractures. (2) Although there was no significant effect on upper arm and ankle fractures in men with T2DM, these results might be unreliable due to the small number of studies included. This finding should be verified in future large-scale cohort studies.

This meta-analysis had several limitations. The DM diagnosis in individual studies was not consistent; this may have introduced confounders in the representative DM cohort. Furthermore, retrospective cohort studies might have introduced recall and selection biases, which could affect the evidence levels and representativeness of the cohorts. In addition, the adjusted models differed across the included studies; these factors might have played important roles in the development of fractures. Additionally, the substantial heterogeneity could not be explored completely due to the unavailability of several important factors, including metabolic syndrome and lifestyle. Finally, there were limitations inherent to any meta-analysis, including publication bias and the lack of availability of individual data.

In conclusion, DM was associated with total, hip, upper arm and ankle fractures. Furthermore, patients with T1DM had a higher risk of total, hip and ankle fractures compared with those with T2DM. There was no sex difference in fractures at different sites. Future studies are warranted to clarify the effect of antidiabetic therapies and investigate effective prevention strategies for fractures at different sites.

Contributors J-LD and HW contributed to the conception and design. HW, YB and QX contributed to acquisition, analysis and interpretation of data. HW and J-LD were involved in drafting or critical revision of the manuscript. All the authors approved the final version.

Funding The authors have not declared a specific grant for this research from any funding agency in the public, commercial or not-for-profit sectors.

Competing interests None declared.

Patient consent for publication Not required.

Provenance and peer review Not commissioned; externally peer reviewed.

Data sharing statement Extra data can be accessed via the Dryad data repository at http://datadryad.org/with the doi:10.5061/dryad.nf15dn8.

Open access This is an open access article distributed in accordance with the Creative Commons Attribution Non Commercial (CC BY-NC 4.0) license, which permits others to distribute, remix, adapt, build upon this work non-commercially, and license their derivative works on different terms, provided the original work is properly cited, appropriate credit is given, any changes made indicated, and the use is non-commercial. See: http://creativecommons.org/licenses/by-nc/4.0/.

\section{REFERENCES}

1. Wild S, Roglic G, Green A, et al. Global prevalence of diabetes: estimates for the year 2000 and projections for 2030. Diabetes Care 2004;27:1047-53.

2. Boyle JP, Honeycutt AA, Narayan KM, et al. Projection of diabetes burden through 2050: impact of changing demography and disease prevalence in the U.S. Diabetes Care 2001;24:1936-40.

3. Ray KK, Seshasai SR, Wijesuriya S, et al. Effect of intensive control of glucose on cardiovascular outcomes and death in patients with diabetes mellitus: a meta-analysis of randomised controlled trials. Lancet 2009;373:1765-72.

4. Peters SA, Huxley RR, Woodward M. Diabetes as a risk factor for stroke in women compared with men: a systematic review and metaanalysis of 64 cohorts, including 775,385 individuals and 12,539 strokes. Lancet 2014;383:1973-80.

5. Tsilidis KK, Kasimis JC, Lopez DS, et al. Type 2 diabetes and cancer: umbrella review of meta-analyses of observational studies. BMJ 2015;350:g7607.

6. Narres M, Claessen H, Droste S, et al. The Incidence of End-Stage Renal Disease in the Diabetic (Compared to the Non-Diabetic) Population: A Systematic Review. PLoS One 2016;11:e0147329.

7. Carnevale V, Romagnoli E, D'Erasmo E. Skeletal involvement in patients with diabetes mellitus. Diabetes Metab Res Rev 2004;20:196-204.

8. Raskin P, Stevenson MR, Barilla DE, et al. The hypercalciuria of diabetes mellitus: its amelioration with insulin. Clin Endocrinol 1978;9:329-35.

9. McNair P, Madsbad S, Christensen MS, et al. Bone mineral loss in insulin-treated diabetes mellitus: studies on pathogenesis. Acta Endocrinol 1979;90:463-72.

10. Vestergaard P. Discrepancies in bone mineral density and fracture risk in patients with type 1 and type 2 diabetes-a meta-analysis. Osteoporos Int 2007;18:427-44.

11. Fan Y, Wei F, Lang Y, et al. Diabetes mellitus and risk of hip fractures: a meta-analysis. Osteoporosis International 2016;27:219-28.

12. Giangregorio LM, Leslie WD, Lix LM, et al. FRAX underestimates fracture risk in patients with diabetes. J Bone Miner Res 2012;27:301-8.

13. Fraser LA, Pritchard J, loannidis G, et al. Clinical risk factors for fracture in diabetes: a matched cohort analysis. $J$ Clin Densitom 2011;14:416-21.

14. Moher D, Liberati A, Tetzlaff J, et al. Preferred reporting items for systematic reviews and meta-analyses: the PRISMA statement. PLoS Med 2009;6:e1000097.

15. Wells G, Shea B, O'Connell D. The Newcastle-Ottawa Scale (NOS) for assessing the quality of nonrandomised studies in meta-analyses. Ottawa (ON: Ottawa Hospital Research Institute, 2009. http://www. ohri.ca/programs/clinical_epidemiology/oxford.htm. 
16. DerSimonian R, Laird N. Meta-analysis in clinical trials. Control Clin Trials 1986;7:177-88.

17. Ades AE, Lu G, Higgins JP. The interpretation of randomeffects meta-analysis in decision models. Med Decis Making 2005;25:646-54.

18. Deeks JJ, Higgins JPT, Altman DG. Analyzing data and undertaking meta-analyses. In: Higgins J, Green S, eds. Cochrane Handbook for Systematic Reviews of Interventions 5.0.1. Oxford, UK: The Cochrane Collaboration, 2008. chap 9.

19. Higgins JP, Thompson SG, Deeks JJ, et al. Measuring inconsistency in meta-analyses. BMJ 2003;327:557-60.

20. Tobias A. Assessing the influence of a single study inmeta-analysis. Stata Tech Bull 1999;47:15-17.

21. Altman DG, Bland JM. Interaction revisited: the difference between two estimates. BMJ 2003;326:219.

22. Li XH, Yu FF, Zhou YH, et al. Association between alcohol consumption and the risk of incident type 2 diabetes: a systematic review and dose-response meta-analysis. Am J Clin Nutr 2016;103:818-29.

23. Egger M, Davey Smith G, Schneider M, et al. Bias in meta-analysis detected by a simple, graphical test. BMJ 1997;315:629-34.

24. Begg CB, Mazumdar M. Operating characteristics of a rank correlation test for publication bias. Biometrics 1994:50:1088-101.

25. Strotmeyer ES, Kamineni A, Cauley JA, et al. Potential explanatory factors for higher incident hip fracture risk in older diabetic adults. Curr Gerontol Geriatr Res 2011;2011:1-8. 2011.

26. Jung JK, Kim HJ, Lee HK, et al. Fracture incidence and risk of osteoporosis in female type 2 diabetic patients in Korea. Diabetes Metab J 2012;36:144-50.

27. Wallander M, Axelsson KF, Nilsson AG, et al. Type 2 Diabetes and Risk of Hip Fractures and Non-Skeletal Fall Injuries in the Elderly: A Study From the Fractures and Fall Injuries in the Elderly Cohort (FRAILCO). J Bone Miner Res 2017;32:449-60.

28. Dobnig H, Piswanger-Sölkner JC, Roth $\mathrm{M}$, et al. Type 2 diabetes mellitus in nursing home patients: effects on bone turnover, bone mass, and fracture risk. J Clin Endocrinol Metab 2006;91:3355-63.

29. Ottenbacher KJ, Ostir GV, Peek MK, et al. Diabetes mellitus as a risk factor for hip fracture in mexican american older adults. $J$ Gerontol $A$ Biol Sci Med Sci 2002;57:M648-M653.

30. Nicodemus KK, Folsom AR. lowa Women's Health Study. Type 1 and type 2 diabetes and incident hip fractures in postmenopausal women. Diabetes Care 2001;24:1192-7.

31. Hothersall EJ, Livingstone SJ, Looker HC, et al. Contemporary risk of hip fracture in type 1 and type 2 diabetes: a national registry study from Scotland. J Bone Miner Res 2014;29:1054-60.

32. Martinez-Laguna D, Tebe C, Javaid MK, et al. Incident type 2 diabetes and hip fracture risk: a population-based matched cohort study. Osteoporos Int 2015;26:827-33.

33. Weber DR, Haynes K, Leonard MB, et al. Type 1 diabetes is associated with an increased risk of fracture across the life span: a population-based cohort study using The Health Improvement Network (THIN). Diabetes Care 2015;38:1913-20.

34. Janghorbani M, Feskanich D, Willett WC, et al. Prospective study of diabetes and risk of hip fracture: the Nurses' Health Study. Diabetes Care 2006;29:1573-8.

35. Oei L, Zillikens MC, Dehghan A, et al. High bone mineral density and fracture risk in type 2 diabetes as skeletal complications of inadequate glucose control: the Rotterdam Study. Diabetes Care 2013;36:1619-28.
36. Ahmed LA, Joakimsen RM, Berntsen GK, et al. Diabetes mellitus and the risk of non-vertebral fractures: the Troms $ø$ study. Osteoporos Int 2006; 17:495-500.

37. Miao J, Brismar K, Nyrén O, et al. Elevated hip fracture risk in type 1 diabetic patients: a population-based cohort study in Sweden. Diabetes Care 2005;28:2850-5.

38. Ivers RQ, Cumming RG, Mitchell P, et al. Blue Mountains Eye Study. Diabetes and risk of fracture: The Blue Mountains Eye Study. Diabetes Care 2001;24:1198-203.

39. Koh WP, Wang R, Ang LW, et al. Diabetes and risk of hip fracture in the Singapore Chinese Health Study. Diabetes Care 2010;33:1766-70.

40. Meyer HE, Tverdal A, Falch JA. Risk factors for hip fracture in middle-aged Norwegian women and men. Am J Epidemiol 1993;137:1203-11.

41. Lipscombe LL, Jamal SA, Booth GL, et al. The risk of hip fractures in older individuals with diabetes: a population-based study. Diabetes Care 2007;30:835-41.

42. Melton LJ, Leibson CL, Achenbach SJ, et al. Fracture risk in type 2 diabetes: update of a population-based study. $J$ Bone Miner Res 2008;23:1334-42.

43. Forsén L, Meyer HE, Midthjell K, et al. Diabetes mellitus and the incidence of hip fracture: results from the Nord-Trøndelag Health Survey. Diabetologia 1999;42:920-5.

44. Holmberg $\mathrm{AH}$, Johnell $\mathrm{O}$, Nilsson PM, et al. Risk factors for fragility fracture in middle age. A prospective population-based study of 33,000 men and women. Osteoporos Int 2006;17:1065-77.

45. Bonds DE, Larson JC, Schwartz AV, et al. Risk of fracture in women with type 2 diabetes: the Women's Health Initiative Observational Study. J Clin Endocrinol Metab 2006;91:3404-10.

46. Leslie WD, Lix LM, Prior HJ, et al. Biphasic fracture risk in diabetes: a population-based study. Bone 2007:40:1595-601.

47. Majumdar SR, Leslie WD, Lix LM, et al. Longer Duration of Diabetes Strongly Impacts Fracture Risk Assessment The Manitoba BMD Cohort. J Clin Endocrinol Metab 2016;101:4489-96.

48. Schwartz AV, Sellmeyer DE, Ensrud KE, et al. Older women with diabetes have an increased risk of fracture: a prospective study. $J$ Clin Endocrinol Metab 2001;86:32-8.

49. Chen HF, Ho CA, Li CY. Increased risks of hip fracture in diabetic patients of Taiwan: a population-based study. Diabetes Care 2008;31:75-80.

50. Shah VN, Shah CS, Snell-Bergeon JK. Type 1 diabetes and risk of fracture: meta-analysis and review of the literature. Diabet Med 2015;32:1134-42.

51. Banciu T, Weidenfeld H, Marcoane E, et al. Serum gammaglutamyltranspeptidase assay in the detection of alcohol consumers and in the early and stadial diagnosis of alcoholic liver disease. Med Interne 1983;21:23-9.

52. Trell E, Kristenson H, Fex G. Alcohol-related problems in middleaged men with elevated serum gamma-glutamyltransferase: a preventive medical investigation. J Stud Alcohol 1984;45:302-9.

53. Yokoyama H, Moriya S, Homma Y, et al. Association between gamma-glutamyl transpeptidase activity and status of disorders constituting insulin resistance syndrome. Alcohol Clin Exp Res 2003;27:22S-5

54. De Laet C, Kanis JA, Odén A, et al. Body mass index as a predictor of fracture risk: a meta-analysis. Osteoporos Int 2005;16:1330-8. 